\title{
Information and Communication Technology (ICT) and Economic Growth in ASEAN-5 Countries
}

\author{
Amy Huong Yong Jing, \\ Faculty of Economics \& Business, Universiti Malaysia Sarawak, Malaysia \\ Rossazana Ab-Rahim \\ Faculty of Economics \& Business, Universiti Malaysia Sarawak, Malaysia
}

Received: March 3, 2020 Accepted: March 30, 2020 Online published: April 1, 2020

doi:10.5296/jpag.v10i2.16589 URL: https://doi.org/10.5296/jpag.v10i2.16589

\begin{abstract}
Digital economy generally refers to a digital technology-based economy. The embrace of digital economy is transforming a nation's economic growth. Countries blessed with successful digitisation will improve their economic performance; hence, it could increase country's GDP growth. In this respect, ASEAN-5 countries becoming a major economic force driver in Asia as well as to the global growth. The goal of this research is therefore to investigate the relationship between ICT and economic growth in the ASEAN-5 countries over the 2003 to 2018 study period. Using static and dynamic panel data estimation, results shows that fixed telephone line subscription has the greatest impact on ICT on economic growth. The findings suggest countries shall focus on the innovation of ICT especially on the mobile-cellular telephone subscription and fixed telephone line subscription to achieve economic growth. Investments in ICT infrastructure foster co-operation in ICT technology as well as advancing ICT particularly on the rise in jobs in the ICT sector, transforming government services into digital form to enhance economic growth in the country.
\end{abstract}

Keywords: information and communication technology, economic growth, ASEAN-5

\section{Introduction}

Information and Communication Technology (ICT) refers to telecommunications that provide mainly communication technology access to information (Seki, 2008). ICT has often studied how modern communication technologies affect society, including Internet and wireless networks, as well as other media through instant messaging, voice over IP (VoIP) and video conferencing. ICT plays a decisive role gaining a competitive advantage over country growth (Seki, 2008). ICT expansion has a promising potential to generate foreign-exchange earnings 
as well as job opportunities to allow a business to increase productivity and benefit (Spiezia, 2012). With the positive contribution expected of ICT development towards a country's economic growth (Roller \& Waverman, 2001).

Economic growth refers to the increase in production of goods and services over a period of time. Economic growth creates more job opportunities in the market cause the income rise (Agarwal, 2011). Purchasing power of the consumers increase and hence drive high economic growth. Economic growth usually measured by gross domestic product (GDP).

At macroeconomic stage, the extension of ICT to economic trends provided the promise of new sources of opportunities for productivity. Evidence showed a good return on investment in the ICT sector combined with the inclusion of human capital in the economy as well as the organizational transition. ICT sector expansion has promising potential to generate both foreign exchange earnings and job opportunities. ICT technology will promote country economic growth (Czernich et al., 2011).

Globalization creates, or replaces, growth and development economies. Nearly every country in the world, including ASEAN nations, carries their economies through ICT activities known as the digital economy. In recent years, ICT innovation has received a great deal of attention from the ASEAN countries, businesses, and regional authorities. ASEAN-5 are being known as the top trends for the "five fastest-growing economies" in South East Asia (Napoleon, 2013) namely Singapore, Thailand, Indonesia, Malaysia and Philippines, which maintain its economic growth at $5 \%$. Countries blessed with the success of ICT innovation will inevitably improve its economic performance. According to the Organization for Economic Cooperation and Development (2014), production and consumption settings are divided around international borders in a conventional sector, focusing primarily on the final good trade. Modern trade through ICT is much better in terms of its data flow, communication and interoperability than traditional trade where its policy focused on market access. The effect of changes in new technology against workers capability will have a significant impact on the country's growth. ICT could be the strike factors to foster the economic growth.

Singapore, in particular, is the way forward to illustrate the growth of e-commerce in the economy. Penetration of the network can become one of the key factors affecting the e-commerce performance in a country. The network penetration rate in Singapore is 73 per cent the highest in the region. Consequently, the increasing presence of ride-sharing services such as Uber, Grab and GO Jek was introduced through a mobile application. Furthermore, with Western Digital and Seagate Technology among the largest producers (Kearney \& Axiata, 2016), Thailand is the world's second-biggest manufacturer of hard disk drives (HDDs) after China in 2015. Communication Technology Policy (2011-2020) as the basis for developing ICT in Thailand serves as the base to move Thailand's economy forward (Charnsripinyo \& Inluksana, 2015). In the last decade, Indonesia has seen slow growth over ICT. According to Eick (2007), Internet Service Provider (IPS) privatization and liberalization only began in the early 1990s with a view to improving the country's telecom availability. Indonesia's government spent just 0.6 percent of its GDP in 2001 on local telecommunications infrastructure, which is much lower compare to the other ASEAN 
country during that period of time (Eick, 2007). The distribution of accessibility toward wireless connection is also skewed toward the big cities with $75 \%$ and $15 \%$ of the country's internet subscribers are located in Jakarta and Surabaya respectively. This shows that the remaining of the country has a limited access toward the wireless connection. The legal infrastructure of e-commerce in Indonesia based on its Electronic Information and Transaction Act 2008 (Ruslijanto, 2012). Indonesia has made significant progress in ICT.

Malaysia is considered one of the high pace developing Asian countries as one of the ASEAN members. Malaysia has managed to introduce e-commerce laws based on the 2006 Electronic Commerce Act and the 2007 Electronic Government Activities Act. In Malaysia, the Personal Data Protection Act was introduced as the first ASEAN member to pass privacy legislation in line with rapid growth of the industry in order to protect the new-emergence segment of consumer known as e-consumers. The Philippines had the fastest growing trend in ICT and were entitled as the country with the fastest growing internet population. ICT is Philippines ' major economic driver. During the early 1990s the Philippines was more open to foreign trade, investments and relations during early of 1990s. First cellular telephone network and first Internet connection in the Philippines allowed widespread of Internet services. E-commerce expected to play a tremendous growth role in the future in the Philippines in the year 2018. Projected to reach USD-million in 2018 (Villegas, 2014), the adaptive of online shopping patterns with growing internet users.

The relationship between ICT and disparity in income stems from uncertainty. Creation of ICTs plays a significant role in helping to alleviate poverty. The overall aim of this study is therefore to explore the relationship between information and communication technology (ICT) and economic growth in ASEAN-5 countries. As far as this study is concerned, existing studies focusing on economic growth in ASEAN countries appear to be limited in ASEAN countries. Past studies such as Farhadi et al (2012) examined the relationship between ICT and economic growth of 159 countries over period 2000 to 2009. This represents an important gap. In this regard, this study aims to investigate the nexus between various ICT services economic growth of ASEAN-5 countries. This analysis can be a useful reference tool in the decision making process for researchers, educators, policy maker and government to understand which ICT indicators shall give emphasize in the attempt to improve economic growth. The next section provides the theoretical rationale with empirical evidence on the topic of ICT and the section on data and methods follows on economic growth. Empirical results will be discussed in the next section, and finally on the conclusion and future direction of the research study.

\section{Literature Review}

Solow (1957) found that the technological progress will boost the economy based on the stock capital in the economy, labor force and the technological factors. The endogenous growth theory is the improving of Solow's model which emphasizes the technical process of the rate of investment, stock of human capital and the size of capital stock. Technological development is described as an endogenous variable that effects on growth. Solow's production function of the Cobb-Douglas type as follows: 


$$
\mathrm{Q}=\mathrm{yK}^{\mathrm{a}} \mathrm{LE} \mathrm{E}^{\mathrm{b}}
$$

where $\mathrm{y}$ is a constant, $\mathrm{a}$ and $\mathrm{b}$ are the marginal efficiency of capital and labor, $\mathrm{Q}$ refers to the level of output, $\mathrm{K}$ refers to the level of capital, $\mathrm{L}$ refers to level of labor while $\mathrm{E}$ refers to the technological progress for examples like improves facilities, education, health and skills. The Solow Model as follows:

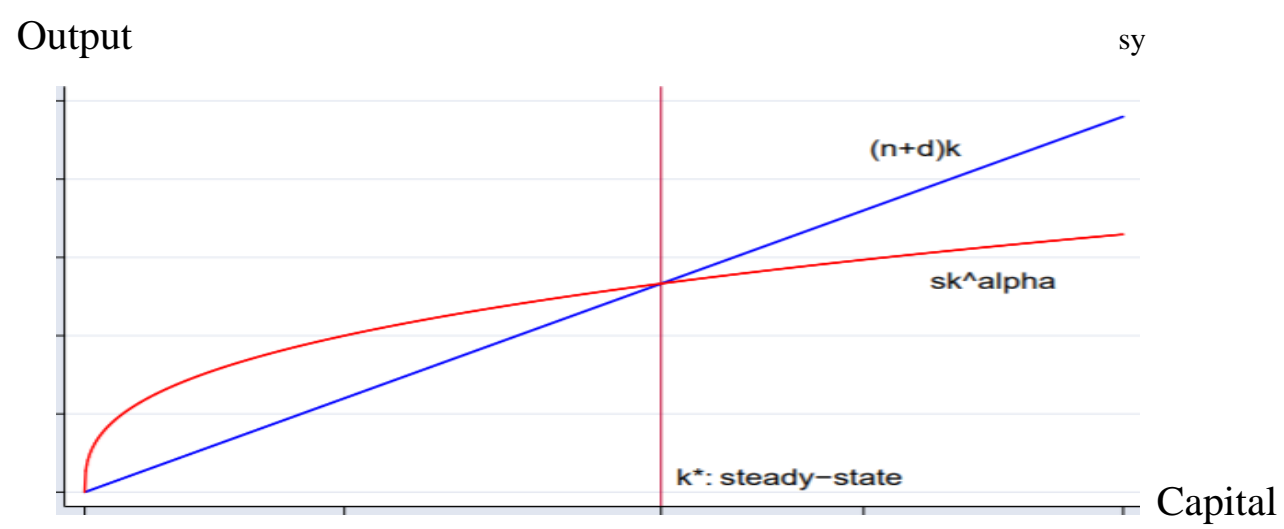

Figure 1. Gross Domestic Product ASEAN-5 (billion U. S. dollars)

Source: Clinton (2005)

where sy = sk $\alpha$ : represents saving (and investment) per capita, $(n+d) k$ : represents the amount of investment needed to keep per capita, $\mathrm{n}$ refers to the population growth and $\mathrm{d}$ refers to the depreciation.

The relationship between ICT and economic growth is not conclusively proven especially in ASEAN-5 countries. Parham (2004) defined growth in ICT adoption as being powered by ICT. ICT increases the country's efficiency and income, while at the same time encouraging the increase of the individual and household income (Spiezia, 2012). Vemuri and Siddip (2009) showed that ICT increased GDP growth especially on e-commerce sites, it contributes towards trades. The expanding of mobile usage increased the income per capita (Haftu, 2019). Broadband increased the efficiency in market processes (Katz, 2012). The relationship was negative due to online shoppers' negative side of behaviours and the maturity level (Chayapa \& Cheng, 2011). The results are mixed.

\section{Data and Methodology}

This study exploits the panel data of the ASEAN-5 namely Singapore, Thailand, Indonesia, Malaysia and Philippines over a period of 2003-2018. The data sets for the variables are obtained from the World Bank Group and International Telecommunication Union. Farhadi et.al (2016) reviews the relationship of the ICT variables: Internet users, mobile cellular telephone subscription, fixed broadband subscription and fixed telephone lines and economic growth. The results showed that ICT had a significant effect on economic growth.

Generally, there are usually two methods of estimating a model based on the assumption made to either use a static panel estimate or a dynamic estimate. This involves Pooled Ordinary Least Squares (POLS) model, Fixed Effect Model (FE) and Random Effect Model 
(RE) for static panel estimation. Firstly, Hausman test is used to test the endogeneity in the explanatory variables (Sheytanova, 2014). Hausman statistic is computed as:

$$
W=\left(\beta_{f e}-\hat{\beta}_{r e}\right)^{\prime}\left(\hat{\Sigma}_{f e}-\hat{\Sigma}_{r e}\right)\left(\beta_{f e}-\hat{\beta}_{r e}\right)
$$

where the covariance matrix for FE and RE models are estimated respectively. If Hausman statistic is bigger than its critical value, null hypothesis is rejected thus the FE model is favorable and vice versa. Meanwhile, Breusch-Pagan statistic is computes as:

$$
L M=\frac{n T}{2(T-1)}\left[\frac{\sum_{i=1}^{n}\left[\sum_{t=1}^{T} e_{i t}\right]^{2}}{\sum_{i=1}^{n} \sum_{i=1}^{T} e_{i t}^{2}}-1\right]^{2}
$$

The null hypothesis in BP-LM test is the residuals across entities are not correlated. If null hypothesis is not rejected, pooled OLS is preferred; otherwise, RE model is better.

Pooled Ordinary Least Squares (POLS) model assumes unobservable characteristic is not correlate with independent variables. POLS model produces BLUE and consistent estimates. However, there is the potential bias POLS where the magnitude problems depend on the model whether it is "fixed" or "random" magnitude (Sheytanova, 2014). POLS model can be expressed in following way:

$$
y_{i t}=\beta_{0}+\beta_{1} y_{i t-2}+\beta_{2} x_{, i t-1}+\ldots+\beta_{k} x_{k, i t-1}+\lambda_{i}+\varepsilon_{i t-1}
$$

Fixed Effect (FE) model is a statistical model of fixed parameters, consisting of the nonrandom quantities when there is an unobserved individual-specific factor found to be correlated with dependent variable. FE model for $\mathrm{k}$ factors can be expressed in following way:

$$
\begin{gathered}
y_{i t}=\beta_{0}+\beta_{1} y_{i t-1}+\beta_{2} x_{, i t-1}+\ldots+\beta_{k} x_{k, i t-1}+\lambda_{i} \varepsilon_{i t-1} \\
y_{i t}=y_{i, t-1}+\alpha_{i}+\beta_{1} x_{1, i t}+\ldots+\beta_{k} x_{k, i t}+\varepsilon_{i t}
\end{gathered}
$$

where no overall intercept included in the model in which are unique and unknown intercept for each individual with the slopes ( $\beta$ parameters) are same for all individuals (Sheytanova, 2014). FE models always gives consistent results for estimates but it is inefficient compare to RE model estimates. FE model can be expressed in following way:

$$
y_{i t}=\alpha_{i}+\beta_{1} x_{1, i t}+\ldots+\beta_{k} x_{k, i t}+\varepsilon_{i t}
$$

Random Effect Model (RE) assumes the difference across entities are random and uncorrelated with the independent variable and randomly distributes across cross-sectional units to capture the individual effects. Intercept term has been specified to represent the overall constant term. RE model can be expressed in following way: 


$$
y_{i t}=y_{i, t-1}+\mu+\beta_{1} x_{1, i t}+\ldots+\beta_{k} x_{k, i t}+\mu_{i t}+\varepsilon_{i t}
$$

Arellano-Bond estimator sometimes known as Arellano-Bond Difference Generalized Moment Method (GMM) used to estimate dynamic panel data models. (Anderson \& Hsiao, 1981). There are three type of Arellano-Bond difference GMM include one step, two step and two steps with robust standard-errors in testing the model. The first-difference of the regression equation has been suggested in Arellano-Bond method to eliminate the country-specific effect as follow:

$$
\left(y_{i t}-y_{i, t-1}\right)=\varphi\left(Y_{, t-1}-y_{i, t-2}\right)+\gamma\left(X_{, t-1}-x_{i, t-2}\right)+\left(v_{i t}-v_{i, t-1}\right)
$$

With the moment conditions of:

$$
E\left[y_{i, y-s}\left(\varepsilon_{i, t}-\varepsilon_{i, t-1}\right)\right]=0 ; s \geq 2 ; t=3, \ldots, T
$$

Specification of model as below:

$$
G D P_{i t}=\beta_{0}+\beta_{1} V O I U_{1, i t}+\beta_{2} M C T_{2, i t}+\beta_{3} F B_{3, i t}+\beta_{4} F T_{4, i t}+\beta_{5} C B_{5, i t}+\beta_{6} P A_{6, i t}+\beta_{7} U R_{7, i t}+\varepsilon_{i t}
$$

where GDP represents economic growth as the dependent variable. VOIU is the volume of internet users, MCT represents the mobile-cellular telephone subscription, FB represents fixed broadband subscription while FT denoted by fixed telephone line subscription. GDP is the economic growth. The controlling variables are crude birth rate, total population aged 65 and urbanization rate. After that, Skewness/Kurtosis test, Wooldridge test and Variance Inflation Factor (VIF) was estimated to ensure the goodness of fits in the model. Autocorrelation is detected by using Wooldridge test. Wooldridge test model as follows:

$$
y_{i t}=\alpha+\beta_{1} X_{i t}+\beta_{2} Z_{i}+u_{i}-\varepsilon_{i t}
$$

where $Y_{i t}$ is the dependent variable and $X_{i t}$ is a $\left(1 \times K_{1}\right)$ vector of time-varying covariates while $\mathrm{Z}_{\mathrm{i}}$ is a $\left(1 \times \mathrm{K}_{2}\right)$ vector of time-invariant covariates. The hypothesis is as below:

$$
\begin{aligned}
& H_{0}=\text { No Serial Correlation } \\
& H_{0}=\text { Serial Correlation }
\end{aligned}
$$

If $\mathrm{H}_{0}$ is rejected, it means there is serial correlation in the model. In order to determine the multicollinearity problem between variables, Variance Inflation Factor (VIF) has been used based on the formula:

$$
V I F_{k}=\frac{1}{1-R_{k}^{2}}
$$

where $R_{k}^{2}$ is the value of $R^{2}$ obtained by the $k$ th predictor regression on the remaining predictors. If the result, $10<\mathrm{VIF}<0.1$ means there is no multicollinearity problems between 
independent variables. Meanwhile, Arellano-Bond difference GMM estimator will be tested by postestimation tests, Sargan Test and AB Test. Sargan Test is being used as for the testing of overidentifying restrictions while $A B$ test is being used to test the residual for serial correlation in the model. The Sargan test hypothesis as below:

$H_{0}: \alpha=0$ Overidentifying restriction instruments are valid; not correlated with errors

$$
H_{1}: \alpha<0 \text { Overidentifying restriction instruments are invalid; correlated with errors }
$$

Under null hypothesis, the test statistic has a distribution with $\mathrm{k}$ equal to total numbers of instruments minus the number of parameters in the model. If $\mathrm{H} 0$ is rejected, it means the IV estimator is biased and inconsistent. The $\mathrm{AB}$ test hypothesis as below:

$$
\begin{gathered}
H_{0}: \alpha=0 \text {; Absence of first order serial correlation (AR1)/ (AR2) } \\
H_{1}: \alpha<0 \text {; Exist of first order serial correlation (AR2)/ (AR2) }
\end{gathered}
$$

If the absence of the second-order serial correlation (AR2) in disturbances is not rejected, it means there is first order serial correlation (AR1) in the model due to the lagged dependent term so it shall not be a problem.

\section{Results and Discussion}

The model is tested by POLS, RE, FE and GMM analysis. The results are presented in Table

\begin{tabular}{|c|c|c|c|c|c|c|}
\hline \multirow{2}{*}{ Variables } & \multicolumn{2}{|c|}{$\begin{array}{l}\text { Pooled OLS } \\
\text { (POLS) }\end{array}$} & \multicolumn{2}{|c|}{$\begin{array}{c}\text { Random Effect } \\
\text { (RE) }\end{array}$} & \multicolumn{2}{|c|}{$\begin{array}{l}\text { Fixed Effect } \\
\text { (FE) }\end{array}$} \\
\hline & Coefficient & (t-test) & Coefficient & (t-test) & Coefficient & (t-test) \\
\hline Constant & 22.660 & $(72.08) * * *$ & 22.660 & $(72.08) * * *$ & 23.680 & $(78.57) * * *$ \\
\hline $\ln \mathrm{VOIU}$ & 0.092 & $(2.00)^{* *}$ & 0.092 & $(2.00) * *$ & 0.068 & (1.36) \\
\hline $\ln \mathrm{MCT}$ & 0.576 & $(10.57)^{* * *}$ & 0.576 & $(10.57)^{* * * *}$ & 0.605 & $(6.72)^{* * *}$ \\
\hline $\ln \mathrm{FB}$ & -0.070 & $(-2.47)^{* *}$ & -0.070 & $(-2.47)^{* *}$ & -0.042 & $(-1.38)$ \\
\hline $\ln \mathrm{FT}$ & 0.200 & $(4.85)^{* * * *}$ & 0.200 & $(4.85)^{* * * *}$ & 0.166 & $(3.14) * * *$ \\
\hline $\mathrm{CB}$ & -0.032 & $(-4.32) * * *$ & -0.032 & $(-4.32) * * * *$ & -0.034 & $(-3.64)^{* * * *}$ \\
\hline PA & 0.036 & $(2.12)^{* * *}$ & 0.036 & $(2.12)^{* * *}$ & 0.089 & $(4.69) * * *$ \\
\hline UR & 0.021 & $(13.36)^{* * *}$ & 0.021 & $(13.36)^{* * * *}$ & -0.0004 & $(-0.10)$ \\
\hline $\begin{array}{l}\text { Hausman } \\
\text { test }\end{array}$ & & & & & $\begin{array}{c}60.90 \\
(\mathbf{0 . 0 0 0})^{* * * *}\end{array}$ & \\
\hline $\begin{array}{l}\text { Breusch-P } \\
\text { agan LM } \\
\text { test }\end{array}$ & & $\begin{array}{c}0.00 \\
(1.0000)\end{array}$ & & & - & \\
\hline
\end{tabular}
1 below.

Table 1. Results of POLS, RE, FE Data Analysis 


\section{MlMacrothink}

Journal of Public Administration and Governance

ISSN 2161-7104

2020, Vol. 10, No. 2

Note: $\ln$ VOIU; Log Volume of Internet Users, $\ln \mathrm{MCT}$; Log Mobile Cellular Telephone Subscription, $\ln \mathrm{FB}$; Log Fixed Broadband Subscription, $\ln \mathrm{FT}$; Log Fixed Telephone Line Subscription, CB; Crude Birth Rate, PA; Total Population Aged 65 and Above; UR; Urbanization Rate

Referring to Table 1, the results for POLS model and RE model that are similar in term of coefficient value which differs by the probability value (p-value) of the variables. Under Hausman null hypothesis as refer to Equation (1) tested, $\mathrm{H}_{0}$ is rejected. P-value is 0 which is less than 0.05, thus Fixed Effect (FE) model is appropriate. Under Breusch-Pagan LM null hypothesis as refer to Equation (2), the p-value is larger than the 5\% significant level which values at 1.000, so POLS model is appropriate. In POLS model, all the variables are significant. The mobile cellular telephone subscription $(\ln \mathrm{MCT})$, fixed telephone line subscription $(\ln \mathrm{FT})$ are significant at $1 \%$ of significance level. Volume of Internet users ( $\ln \mathrm{VOIU})$ and the fixed broadband subscription $(\ln \mathrm{FB})$ are significant at $5 \%$ of significance level. Meanwhile, control variables, crude birth rate (CB) and urbanization rate (UR) are significant at $1 \%$ significance level while total population aged 65 and above (PA) is significant at 5\% significance level. As for FE model, two ICT independent variable significant at $1 \%$ significance level which are mobile cellular telephone subscription $(\ln \mathrm{MCT})$ and fixed telephone line subscription $(\ln \mathrm{FT})$. Control variables, crude birth rate (CB) and total population aged 65 and above (PA) are significant at $1 \%$ significance level. Hence, Pooled Ordinary Least Square (POLS) model is appropriate.

Table 2. Skewness/Kurtosis Tests Results

\begin{tabular}{|c|c|}
\hline Probability (Skewness) & 0.7590 \\
Probability (Kurtosis) & 0.6134 \\
Probability of Chi-Square & 0.8381 \\
Observation & 80 \\
\hline
\end{tabular}

The model being tested for its normality and the results are shown in Table 2. The results show that P-value (Prob. Chi-Square) is 0.8381 which is more than $5 \%$ significance level, $\alpha$ $=0.05$. Thus, we fail to reject the $\mathrm{H}_{0}$ and it means that the null hypothesis of variables is normally distributed in the model is being accepted.

Table 3. Goodness of Fit Tests Results

\begin{tabular}{lc}
\hline Heteroscedasticity & 70.96 \\
(White test-chi stat) & $(\mathbf{0 . 0 0 0 3})^{* * *}$ \\
Serial Correlation & 16.607 \\
(Wooldridge test- F stat) & $\mathbf{( 0 . 0 1 5 2 ) * *}^{* *}$ \\
Multicollinearity & 7.68 \\
(mean VIF) & \\
\hline
\end{tabular}

Note: $* *, * * *$ indicate $5 \%$ and $1 \%$ significance level

From the diagnostic results computed, the heteroscedasticity result shows in Table 3 that the Pvalue (Prob. Chi-Square) is 0.0003 which is lower than 5 percent significance level, $\alpha=0.05$. Thus, $\mathrm{H}_{0}$ is rejected. The variances are not constant in the model. The correlation result show 
that p-value (Prob. F stat) is 0.0152 which is lower than 5 percent significance level, $\alpha=0.05$. Thus, $\mathrm{H}_{0}$ is rejected and it means that there is serial correlation in the model. Hence, the model needs to be corrected. Based on the assumption of $10<\mathrm{VIF}<0.1$ where the result shows the mean VIF is 7.68 , it means there is no multicollinearity problems between independent variables.

The corrected POLS model is written as,

$$
\begin{gathered}
\log G D P_{i t}=3.686+0.019 \log V O I U_{1, i t}-0.095 \log M C T_{2, i t}+0.042 \log F B_{3, i t}-0.023 \log F T_{4, i t} \\
+0.24 C B_{5, i t}+0.035 P A_{6, i t}-0.086 U R_{7, i t}+\varepsilon_{i t}
\end{gathered}
$$

$\beta_{0} \mathrm{~s}$ the intercept of the model, which is 3.686. $\beta_{1}$ is the coefficient of volume of online users, which is 0.013 . An increase in the volume of internet users of $1 \%$, on average, will leads to an estimated increase in economic growth by $0.019 \%$. There is a positive relationship between internet user volume and economic growth because the use of Internet minimising the transaction cost during the business process (Vemuri \& Siddip, 2009), $\beta_{2}$ is the coefficient of mobile cellular telephone subscription, which is -0.095 . An increase in the mobile cellular telephone subscriptions by $1 \%$, on average, leads to a decline in economic growth by $0.92 \%$. There is a negative relationship between mobile cellular telephone subscription and economic growth. According to study by Arthur (2019), the use of mobile cellular creates large bills. Extra expenses needed to own a mobile phone caused the consumers unable to spend on other items and it hurts economy as whole. $\beta_{3}$ is the coefficient of fixed broadband subscription, which is 0.042 . An increase in the fixed broadband subscription of $1 \%$, economic growth will increase by $0.042 \%$. There is a positive relationship between fixed broadband subscription and economic growth (Katz, 2017). Fixed broadband subscriptions become the key of transformative power to increase the efficiency in the market. $\beta_{4}$ is the coefficient of fixed telephone line subscription, which is -0.023. An increase in the fixed telephone line subscription by $1 \%$, on average, leads to decrease in the economic growth by $0.023 \%$. It is because the installation of infrastructure to diffuse fixed telephone lines over the territories is costly in Sub-Saharan Africa region (Albiman \& Sulong, 2016). In the early period, fixed telephone line interacted positively with economic growth but negatively after it being replaced by mobile cellular (Ward \& Zheng, 2016).

Generally, the study estimated that there is a positive relationship between the economic growth in the ASEAN-5 ( $\left.\ln \mathrm{GDP}_{\mathrm{it}}\right)$ with the volume of internet users (lnVOIU), the mobile-cellular telephone subscription $(\ln \mathrm{MCT})$ and the fixed telephone line subscription $(\ln \mathrm{FT})$. Meanwhile, the fixed broadband subscription $(\ln \mathrm{FB})$ had a negative impact economic growth $(\ln \mathrm{GDP})$. 


\section{MInstitute ${ }_{\text {Mnk }}^{\text {Macrothin }}$}

Table 4. Results of GMM Data Analysis

\begin{tabular}{|c|c|c|}
\hline Variables & \multicolumn{2}{|c|}{ Arellano-Bond (1991) difference GMM One Step (constant=0) } \\
\hline & Coefficient & (t-test) $)^{\text {slg. Ievel }}$ \\
\hline lagGDP & 0.579 & $(8.04)^{* * *}$ \\
\hline $\ln \mathrm{VOIU}$ & 0.029 & $(0.96)$ \\
\hline $\ln \mathrm{MCT}$ & 0.242 & $(2.59) * * *$ \\
\hline $\ln \mathrm{FB}$ & -0.016 & $(-0.49)$ \\
\hline $\ln \mathrm{FT}$ & 0.097 & $(3.03)^{* * * *}$ \\
\hline $\mathrm{CB}$ & -0.011 & $(-1.64) *$ \\
\hline PA & 0.024 & $(1.85)^{*}$ \\
\hline UR & 0.0004 & $(0.01)$ \\
\hline $\begin{array}{l}\text { Sargan Test } \\
\text { (prob chi-square) }\end{array}$ & 70.35 & $(0.1479)$ \\
\hline $\begin{array}{l}\text { AB Test } \\
\text { (prob-z) }\end{array}$ & & $\begin{array}{l}1=(-2.60) * * * * \\
2=(-0.67)\end{array}$ \\
\hline
\end{tabular}

Note: lagGDP; Lag Gross Domestic Product, $\ln$ VOIU; Log Volume of Internet Users, $\ln \mathrm{MCT}$; Log Mobile Cellular Telephone Subscription, $\ln \mathrm{FB}$; Log Fixed Broadband Subscription, $\ln \mathrm{FT}$; Log Fixed Telephone Line Subscription, CB; Crude Birth Rate, PA; Total Population Aged 65 and Above; UR; Urbanization Rate

Dynamic panel estimation, Arellano-Bond difference GMM in One Step with zero constant, referring back to estimation result in Table 4, only two ICT independent variables are significant, the mobile cellular telephone subscription ( $\ln \mathrm{MCT})$ and fixed broadband subscription $(\ln \mathrm{FB})$ are significant at $1 \%$ significance level. Control variables, crude birth rate (CB) and total population aged 65 and above (PA) are significant at 10\% significance level. The Arellano-Bond difference GMM-One Step model is written as:

$$
\begin{gathered}
\log G D P_{i t}=0.579 \operatorname{lag} G D P+0.029 \operatorname{logVOI} U_{1, i t}+0.242 \log M C T_{2, i t}-0.016 \log F B_{3, i t}+0.09097 \log F T_{4, i t} \\
-0.011 C B_{5, i t}+0.024 P A_{6, i t}+0.0001 U R_{7, i t}+\varepsilon_{i t}
\end{gathered}
$$

$\lambda$ is the coefficient of lagged dependent variable of economic growth (lagGDP), which is 0.579. There is an effect of past dependent on current dependent as it is significant at $1 \%$ significance level. $\beta_{1}$ is the coefficient of volume of online users, which is 0.029 . An increase in volume of internet users of $1 \%$, on average, leads to increase in economic growth by $0.029 \%$. There is a positive relationship between volume of online user and economic growth. $\beta_{2}$ is the coefficient of mobile-cellular telephone subscription, which is 0.242 . An increase in mobile-cellular telephone subscription of $1 \%$, on average, leads to decrease in economic growth by $0.242 \%$. There is a positive relationship between mobile-cellular telephone subscription and economic growth. $\beta_{3}$ is the coefficient of fixed broadband subscription, which is -0.016 . An increase in fixed broadband subscription of $1 \%$, on average, leads to decrease in economic growth by $0.016 \%$. There is a negative relationship between fixed 
broadband subscription and economic growth, which is different with our prediction before. $\beta_{4}$ is the coefficient of fixed telephone line subscription, which is 0.097. An increase in fixed telephone line subscription of $1 \%$, on average, leads to increase in economic growth by $0.097 \%$. There is a positive relationship between fixed telephone line subscription.

For Sargan test, the result (Refer Table 4) proves that overidentifying restriction instruments are valid in the model as the p-value (Prob. Chi-Square) is 0.1479 which is more than 5 percent significance level, $\alpha=0.05$. Thus, $\mathrm{H}_{0}$ is not rejected and it means that the null hypothesis of overidentifying restriction instruments are valid in the model and it is not correlated with the errors. Meanwhile, according to $\mathrm{AB}$ test, no second order serial correlation exists in the model.

Table 5. Results of Corrected POLS Model and Arellano-Bond Difference GMM

\begin{tabular}{|c|c|c|c|c|}
\hline \multicolumn{5}{|c|}{ Model Analysis } \\
\hline \multirow[t]{2}{*}{ Variables } & \multicolumn{2}{|c|}{$\begin{array}{l}\text { Pooled OLS } \\
\end{array}$} & \multicolumn{2}{|c|}{ Arellano-Bond Difference GMM } \\
\hline & Coefficient & $(t \text {-test })^{\text {sig. Iever }}$ & Coefficient & $\left(\right.$ t-test $^{\text {sIg. Ievel }}$ \\
\hline Constant & 3.686 & $(5.02) * * *$ & & \\
\hline lagGDP & & - & 0.579 & $(8.04) * * *$ \\
\hline $\ln \mathrm{VOIU}$ & 0.019 & $(0.73)$ & 0.029 & $(0.96)$ \\
\hline $\ln \mathrm{MCT}$ & -0.095 & $(-4.79) * * *$ & 0.242 & $(2.59) * * *$ \\
\hline $\ln \mathrm{FB}$ & 0.042 & $(1.64)$ & -0.016 & $(-0.49)$ \\
\hline $\ln \mathrm{FT}$ & -0.023 & $(-1.66)$ & 0.097 & $(3.03) * * *$ \\
\hline $\mathrm{CB}$ & 0.240 & $(2.49) *$ & -0.011 & $(-1.64)^{*}$ \\
\hline PA & 0.035 & $(0.31)$ & 0.024 & $(\mathbf{1 . 8 5}) *$ \\
\hline UR & -0.086 & $(-1.31)$ & 0.0004 & $(0.01)$ \\
\hline
\end{tabular}

Note: lagGDP; Lag Economic Growth, $\ln$ VOIU; Log Volume of Internet Users, $\ln \mathrm{MCT}$; Log Mobile Cellular Telephone Subscription, $\ln \mathrm{FB}$; Log Fixed Broadband Subscription, $\ln \mathrm{FT}$; Log Fixed Telephone Line Subscription, CB; Crude Birth Rate, PA; Total Population Aged 65 and Above; UR; Urbanization Rate

For the POLS model, the mobile cellular telephone subscription $(\ln \mathrm{MCT})$ is significant at $1 \%$ significance level. Besides, the crude birth rate (CB) is significant at $10 \%$ significance level. Besides, for the robust Arellano-Bond difference GMM model, the lagged dependent is significant to justify the model is dynamic. From the estimated result, the mobile cellular telephone subscription $(\ln \mathrm{MCT})$ and fixed telephone line subscription $(\ln \mathrm{FT})$ are significant at $1 \%$ significance level. Meanwhile, the crude birth rate $(\mathrm{CB})$ and total population aged 65 and above (PA) are significant at 5\% significance level. Hence, Arellano-Bond difference GMM model is valid as the final model of this study. 


\section{Conclusion}

This study examines the relationship between ICT and economic growth in ASEAN-5 countries over the study period of 2003 until 2018. GMM model being used as the final model to estimate the relationship between ICT and economic growth of the countries; whereby the mobile cellular telephone subscription $(\ln \mathrm{MCT})$ and fixed telephone line subscription $(\ln \mathrm{FT})$ in ASEAN-5 countries has a significant positive effect on the economic growth which are significant at $1 \%$ significance level. The fixed telephone line subscription $(\ln \mathrm{FT})$ is the most significant factor among the ICT independent variables that influence the economic growth, which is 0.097 with its p-value, 0.002. An increase $1 \%$ in fixed telephone line subscription on average, leads to increase in economic growth by $0.097 \%$. The results show that ICT does affect the economic growth in ASEAN-5 countries. Hence, the ICT development should be considered in any future policies to combat the economic growth in ASEAN-5 countries. Regulatory policies are crucial to develop the infrastructure to foster higher level of ICT use to increase the economic growth in the country. From the results, it can be inferred that the economic growth of ASEAN-5 can be fostered through the implementation of its ICT policy to combat poverty. Investment in government infrastructure and policy development that promotes the growth of the ICT sector in the ASEAN-5 countries would enhance the economic growth in the country. Besides, government can provide the public with up-to-date structure and educate people on the efficiency of ICT used. This study suggests for future research to cover a longer time span to shed light in the assessment of the relationship between ICT and economic growth.

\section{References}

Agarwal, P. (2020, February 11). Equitable Distribution of Income. Intelligent Economist. https://www.intelligenteconomist.com/equitable-distribution-of-income

Albiman, M. M., \& Sulong, Z. (2016). The Role of ICT Use to The Economic Growth in Sub aharan African Region. Journal of Science and Technology Policy Management, 7(3), 306-329.

Arellano, M., \& Bond, S. (1991). Some Tests of Specification for Panel Data: Monte Carlo Evidence and an Application to Employment Equations. Review of Economic Studies, 58(2), 277-297.

Arthur, L. (2019). Economic Problems Caused by the Use of Cellphones [Abstract]. It Still Works. Retrieved from https://itstillworks.com/problems-cellphone-use-manufacturing-plants -plants-12195045.html

Anderson, T.W., \& Hsiao, C. (2012). Estimation of Dynamic Models with Error Components. American Statistical Association, 76(375), 598-606.

Charnsripinyo, C., \& Inluksana, S. (2015. September 8). National Broadband Policy [Slides]. Ministry of Digital Economy and Society Thailand. http://www.mdes.go.th/view/10/Al 1News/e-Publication/24

Chayapa, K., \& Cheng, L. W. (2011). Online Shopper Behavior: Influences of Online 
Shopping Decision. Asian Journal of Business Research, 1(2), 67-74.

Clinton, K. (2005). Economic Growth: Solow Model [Infographic]. Queen's Economics Department. http://qed.econ.queensu.ca/pub/faculty/clintonk/econ223/3\%20Solow\%20growt h\%20model.pdf

Czernich, N., Falck, O., Kretschmer, T., \& Woessmann, L. (2011). Broadband infrastructure and economic growth. The Economic Journal, 121(552), 505-532.

Eick, S. (2007). A History of Indonesian Telecommunication Reform 1999-2006. Proceedings of 40th Annual Hawaii International Conference on System Sciences No. 1530-1605/07. Institute of Electrical and Electronics Engineers Xplore Digital Library. http://ieeexplore.ieee.org/ docum ent/4076507/citations\#citations

Farhadi, M., Ismail, R., \& Fooladi, M. (2012). Information and Communication Technology Use and Economic Growth. Plos One, 7(11), 1-7.

Gujarati, D.N., \& Porter, D.C. (2009). Basic Econometric. United States: McGraw-Hill.

Iacovone, L., \& Pereira-Lopez, M. (2018, January 10). ICT Adoption and Wage Inequality: Evidence from Mexican Firms. (World Bank Policy Research Working Paper No. 8298). Social Science Research Network. https://papers.ssrn.com/sol3/papers.cfm?abstract_id = 309920bstract_id=3099205

Ismail, M. (2018, July 17). Southeast Asia's widening inequalities. The ASEAN Post. https: //thease anpost.com/article/southeast-asias-widening-inequalities

Katz, R. (2012, April 1). The Impact of Broadband on the Economy. International Telecommu nication Union. https://www.itu.int/ITU-D/treg/broadband/ITU-BBReports_Impact-of-Broad band-on-the-Economy.pdf

Kearney, A. T., \& Axiata (2016). The ASEAN Digital Evolution. Kearney. https://www.kearney.com/digital-transformation/article?/the-asean-digital-revolution

Kuznet. (1955). Economic Growth and Income Inequality. The American Economic Review, 45(1), 1-28.

Moffatt, M. (2019). Essential Economics Terms: Kuznets Curve. ThoughtCo https://www.t houghtco.com/kuznets-curve-in-economics-1146122

Napoleon, E. (2013). A Short Comparative Overview of the ASEAN 5 Countries Economic and Scientific Activities. International Journal of Asian Social Science, Asian Economi $c$ and Social Society, 3(7), 1648-1657.

Parham, D. (2004). Sources of Australia's Productivity Revival. Economic Record, 80(249), 239-257.

Roller, L \& Waverman, L. (2001). Infrastructure and Economic Development: A Simultaneous Approach. American Economic Association, 91(4), 909-923.

Ruslijanto, P. A. (2012). Digital Signature's Legal Position in Electronic Commerce. 
Internatioal Conference on Economics Marketing and Management. International Proceedings of Economics Development and Research. http://www.ipedr.com/vol28 136-ICEM M2012-G00001.pdf

ScienceDirect. (2019). Kuznets curve. Science Direct Portal. https://www.sciencedirect.co $\mathrm{m} /$ topics/economics-econometrics-and finance/kuznets-curve

Seki, Y. (2008). The Importance of ICT for the Knowledge Economy: A Total Factor Productivity Analysis for Selected OECD Countries. Proceedings of the Annual IUE- SUNY Cortland Conference in Economics. Izmir University of Economics. https://idea s.repes.org/h/izsm/prcdng/200804.html

Sheytanova, T. (2014, April 9). The Accuracy of the Hausman Test in Panel Data: A Monte Carlo Study. Orebro University School of Business. http://oru.diva-portal.org/smash/g t/diva2:805823/FULLTEXT01.pdf

Solow, RM. (1957). Technical Change and the Aggregate Production Function. The Review of Economics and Statistics, 39(3), 312-320.

Spiezia, V. (2012), ICT investments and productivity: Measuring the contribution of ICTS to growth. OECD Journal: Economic Studies, 1, 199-211.

Vemuri, V. K., \& Siddiqi, S. (2009). Impact of Commercialization of the Internet on International Trade: A Panel Study Using the Extended Gravity Model. The International Trade Journal, 23(4), 458-484.

Villegas, B. M. (2014). The ICT Sector in the Philippine Economy. Nomura Foundation. https:/www.nomurafoundation.or.jp/en/wordpress/wpcontent/uploads/2014/09/20010525_Ber nardo_Villegas.pdf

Vokshi, M.C., Dedaj B., Youssef, A.B., \& Toci, V. (2019). Mobile phone penetration and its impact on inequality in the Western Balkan countries. Zagreb International Review of Economics \& Business, 22(2), 111-131.

Ward, M. R., \& Zheng, S. (2016). Mobile telecommunications service and economic growth: Evidence from China. Telecommunications Policy, 40(2), 89-101.

World Bank. (2019). GINI index (World Bank estimate) [Data]. The World Bank Database. http://data.worldbank.org/indicator/SI.POV.GINI

\section{Copyright Disclaimer}

Copyright for this article is retained by the author(s), with first publication rights granted to the journal.

This is an open-access article distributed under the terms and conditions of the Creative Commons Attribution license (http://creativecommons.org/licenses/by/4.0/). 